\title{
Editorial: multicriteria assessment of livestock systems using a graphical tool
}

\author{
G. Richard ${ }^{1 \dagger}$, A. Bernues ${ }^{2}$ and J. -Y. Dourmad ${ }^{3}$ \\ ${ }^{1}$ UAR1241 DEPE, INRA, 147 rue de I'Université, 75338 PARIS Cedex 07, France; ${ }^{2}$ Centro de Investigación y Tecnología Agroalimentaria de Aragón (CITA), Instituto \\ Agroalimentario de Aragón (IA2, CITA-Universidad de Zaragoza), Avda. Montañana 930, 50059 Zaragoza, Spain; ${ }^{3}$ UMR 1348 PEGASE, INRA, 16 le clos, Domaine de \\ La Prise, 35590 Saint-Gilles, france
}

Globally, livestock farming is a socially, environmentally and politically significant rural activity, even if its economic contribution is modest (Steinfeld et al., 2006). Livestock farming systems cover $70 \%$ of global agricultural land $(50 \%$ in EU), most of it as pasture. They significantly contribute to the supply of human food, mainly as protein- $30 \%$ at world level and more than $50 \%$ at EU level. Through their utilization of agricultural land and the acceleration of nutrient cycling via manure, they also generate significant ecosystem services in terms of plant and animal biodiversity, pollination, water quality, soil fertility and cultural ecosystem services.

Nevertheless, livestock farming is highly questioned by the society due to its impact on the environment (global warming, eutrophication, acidification, and land, water and energy use), on human health (air and water pollution, and risks linked to overconsumption of animal products), and on animal welfare.

Determining the optimal balance-in a diversity of areas and ecosystems-between positive and negative contributions of livestock farming systems to social, environmental and economic sustainability is thus a crucial political and scientific challenge. In this context, the French Ministries overseeing agriculture and the environment, in cooperation with the French Agency for environment and energy management (ADEME) requested INRA to carry out a collective Scientific Assessment addressing these questions. The goal is to review scientific knowledge and to contribute to the societal debate on livestock farming. The two review articles presented below (Ryschawy et al., 2019; Dumont et al., 2019), are products of this scientific assessment on the role, impacts and services provided by European livestock production.

A multidisciplinary analysis of the international scientific literature on the various dimensions of sustainability yielded the concept of "Bundles of Services". This concept calls for a global and systemic approach based on multicriteria analyses of livestock systems (Ryschawy et al., 2019). It was already proposed by Martín-López et al. (2012) and is here applied to

\footnotetext{
${ }^{\dagger}$ E-mail: guy.richard@inra.fr
}

a range of livestock farming systems and production areas. To identify synergies and trade-offs between "services", this approach aggregates: (i) ecosystem services arising from grasslands and associated biodiversity; (ii) negative externalities, such as contribution to global warming and pollution of water and air; (iii) production services including provision of human food and contribution to the global economy; (iv) social dimensions such as "employment", perception by citizens, and cultural heritage (gastronomy, landscape aesthetic value, etc.); and (v) use of external inputs and resources.

A unique graphical tool coined "The Barn" is derived from this social-ecological approach to comprehensively represent the whole "bundle of services". Quantitative indicators are available at a variety of scales for variables that regard products, inputs, jobs, or emissions to the environment. Indicators available for social and cultural dimensions, and for some of the environmental variables such as biodiversity, sensitivity to drought, and risk of predation, are fewer in numbers and mainly qualitative in nature. Whether easy or difficult to quantify, the inclusion of these variables acknowledges their importance. This tool applies at different scales ranging from farm to region. At the regional scale, the barn represents the dominant system; it is however also possible to represent market niches often hidden by the dominant socio-technical system. The graphical nature of this tool makes it well adapted to support decision making or teaching.

Using two simple criteria, i.e., animal density and the relative abundance of permanent grassland, livestock production areas with contrasted "bundles of services" were mapped at EU scale, and summarized graphically using the "barn" framework to represent their specific associations among goods, impacts and ecosystems services (Dumont et al., 2019). Independent of scale, trade-offs often appear between production, regulation and cultural services. Exploratory scenarios to evaluate the consequences of alternative strategies that break away from current production, legislation and consumption patterns nevertheless bear out the possibility of win-win strategies according to the balance between societal, environmental and productive goals. 
As illustrated in the two papers, the concept of "bundles of services" with its graphical "barn" framework offers an integrated - albeit qualitative - vision that summarizes the ecological and socioeconomic dimensions of livestock farming. These innovative tools can be used at various geographical or organizational scales. They can promote knowledge exchange and sharing different viewpoints between a wide diversity of stakeholders to explore key livestock production threats and opportunities.

This work highlights and questions the major issues we face today regarding thresholds and boundaries to be considered when evaluating and redesigning livestock production. Should we assign different weights to the different economic, social, and environmental dimensions according to geographical area, or type of production chain? Can we extend our framework to evaluate alternative land uses that include a diversity of options such as mixed crop-livestock systems, agroforestry, landscape conservation, or biomass production for industry?

This work also echoes questions raised by the Bioeconomy framework, which aims to comprehensively address challenges regarding food security, fossil fuel dependency, climate change, natural resources, and ecosystem services, while achieving sustainable development (Dubois and Gomez San Juan, 2016).

\section{References}

Dubois 0 and Gomez San Juan M 2016. How sustainability is addressed in official bioeconomy strategies at international, national and regional levels. An overview. FA0, Rome, Italy.

Dumont B, Ryschawy J, Duru M, Benoit M, Chatellier V, Delaby L, Donnars C, Dupraz P, Lemauviel-Lavenant S, Méda B, Vollet D and Sabatier R 2019. Review: Associations among goods, impacts and ecosystem services provided by livestock farming. Animal 13, 1773-1784.

Martín-López B, Iniesta-Arandia I, García-Llorente M, Palomo I, Casado-Arzuaga I and Amo DGD 2012. Uncovering Ecosystem Service Bundles through Social Preferences. PLoS ONE 7, e38970. https://doi.org/10.1371/journal.pone.0038970.

Ryschawy J, Dumont B, Therond O, Donnars C, Hendrickson J, Benoit M and Duru M 2019. Review: An integrated graphical tool for analyzing impacts and services provided by livestock farming. Animal 13, 1760-1772.

Steinfeld H, Gerber P, Wassenaar T, Castel V, Rosales M and de Haan C 2006. Livestock's long shadow. FAO, Rome, Italy. 